\author{
ALEKSANDER GRZELAK' \\ MICHAŁ BORYCHOWSKI \\ JAKUB STANISZEWSKI
}

\title{
Pro-environmental actions of agricultural farms - example of holdings from the Wielkopolska region
}

Professor Aleksander Grzelak, Poznań University of Economics and

Business,

Faculty of Economics,

Poland,

ORCID: 0000-0002-4290-4740.

Michał Borychowski, Ph.D., Poznań University of Economics and

Business,

Faculty of Economics,

Poland,

ORCID: 0000-0001-6256-2680.

Jakub Staniszewski, Ph.D.,

Poznań University of Economics and

Business,

Faculty of Economics,

Poznań University of Economics and

Business,

Poland,

ORCID: 0000-0001-8074-0911.

\section{Introduction}

Reducing negative environmental impact the main challenges facing global (FAO 2014) and European (DG AGRI, 2017) agriculture. There are a lot of studies proving the negative consequences of over-exploitation of the environment by agricultural production in Europe. The negative effects of unsustainable agricultural production concern: (1) loss of landscape diversity and biodiversity; (2) soil erosion; (3) over- or under-fertilisation and pollution by plant protection products; (4) over-use and pollution of groundwater; (5) greenhouse gas emissions (Stoate et al., 2009). In Poland, in particular, the threats of agricultural activity to the environment result from inaccurate use, storage and disposal of pesticides, intensive mineral fertilization, inadequate protection, as well as management of animal manure (in the case of intensive pig and poultry farms). Also inappropriate storage, transport of silage, and plant waste are important here (Bujanowicz and Haraś, 2007). On the other hand, the still relatively

1 The paper was financed under the funds of the National Science Centre in Poland (Grant no. 2018/29/B/HS4/01844). 
low level of education is a barrier to the dissemination of appropriate practices in agricultural production. However, many practices can mitigate environmental damage. A review of best practices in the area of air, soil and water protection is carried out by Martinho (2019).

Problems connected with environmental issues in agricultural holdings are complex. For example, D'Souza and Ikerd (1996) suggested that large (industrial) farms due to their size, mechanization and specialization (and other reasons) tend to decline the sustainability of agriculture. In turn small farms in respect of the lower intensity of land use and providing of public goods contribute (to a larger extent) to environmental sustainability. On the other hand (Westbury et al., 2012) pointed out the significant effect of the farm size on the environmental performance of lowland livestock farms. According to them, the bigger the holding, the better the environmental performance (measured by the Agri-Environmental Footprint Index). They stressed that large farms use land less intensively, and provide greater proportions of low-input habitats, increasing the values of land use diversity. In contrast, small livestock farms use more energy and water per ha of utilizable agricultural area (compared with the large farms). Increasingly, such research is also undertaken in the context of climate change (Ahmed and Stepp, 2016). Therefore, an important task is to identify the scope of proenvironmental measures taken by farmers.

One of the basic sources of information on agricultural activity in the EU is the FADN (Farm Accounting Data Network) system, however, its capacity to report on environmental issues is limited (Kelly et al., 2018). Therefore, surveys are undertaken to supplement the information from the FADN. In Poland, such surveys have recently been conducted by Piwowar (2020), Baum and Bieńkowski (2020), Syp and Osuch (2019), Sulewski and Kłoczko-Gajewska (2018), ŚmiglakKrajewska (2018) or Świtek and Sawińska (2017). The results presented in this paper are in line with this research trend. In turn, the theoretical basis for the considerations contained in the study refers to the environmental economics (Żylicz, 2004) as well as the economics of sustainable development (Rogal, 2004). The growing interest in sustainable development, including environmental issues, has been the main driver for the operation of programs under various the EU funds for over two decades. These processes take place under conditions of decreasing the importance of agriculture in shaping the GDP in Poland. Nevertheless, the position of this sector in terms of the EU and national budget expenditures is still strong. Moreover, the situation in foreign trade in agri-food products is also definitely favourable. 
The main aim of the study is to identify the pro-environmental activities in farms in Wielkopolska. It is not only about examining the universality of these processes, but also their character, as well as diagnosing the characteristics of farms (their managers), which are most active in the area of these activities. For this reason, the research is both scientific (determination of relations between pro-environmental activity of farmers and selected economic categories) and applicable (context of the CAP (Common Agricultural Policy) evolution directions). The latter is also a question of whether the current pro-environmental trend in farm support should be maintained or extended. The time scope of the analyses referred to the period 2016-2019 and in the case of economic data to 2018.

\section{Research materials and methodology}

The article uses the results of a survey carried out in 2020 in a group of 120 farms from Wielkopolska that run agricultural accounting according to the FADN system. The research tool was an interview questionnaire entitled: "Assets and income in agricultural holdings in the paradigm of sustainable development". The choice of farms in this region resulted from their relatively more marketoriented attitude to the situation in the country. In turn, the limited sample size resulted mainly from financial reasons. However, it is considered that with the numbers of 100 units or more, the bias on the estimator is insignificant (Zasepa, 1972). The selection of holdings for the sample was based on the economic size of the holding (ES6) ${ }^{2}$ and production types (TF8) ${ }^{3}$. Due to the relatively low number of farms from groups ES1 and ES6 which run agricultural accounting in Wielkopolska, units from groups ES2-ES5 were selected for the research. In the case of production types of farms, farms specializing in field production (TF1), milk production (TF5), other grazing livestock (TF6), granivores (TF7) and mixed (TF8) were included. Quota selection of the number of farms for the survey was applied. The obtained results are not representative for farms in Poland (also for

2 The economic size (ES - economic size) of farms is expressed through the value of the farms' standard output (in EUR thousand): ES1 - very small farms with the annual output value of 2-8; ES2 - small 8-25; ES3 - medium-small 25-50; ES4 - medium-large 50-100; ES5 - large 100-500; ES6 - very large $>500$.

3 TF (type of farming) - the system for distinguishing eight types of production of agricultural holdings within the framework of the EU FADN agricultural accounting according to the predominant production direction.

Pro-environmental actions of agricultural

farms - example of holdings

from the Wielkopolska region 
these covered by the FADN system $)^{4}$. On the other hand, it better illustrates the situation and behaviour of farms with a stronger market orientation. Therefore, the results of these farms may indicate predictive tendencies in the scope of the examined phenomena and treat them as signaling.

\section{Results and discussion}

Out of 120 agricultural holdings surveyed, 102 agricultural producers declared that in 2016-2019 measures were taken to improve the natural environment (pro-environmental actions), so only $15 \%$ of the respondents were not involved in any of the initiatives ${ }^{5}$. The greatest interest was associated with afforestation of land (as many as 61 farms, i.e. more than $50 \%$ of all) were involved in this form of action, and in next places farmers indicate thermo-modernisation of buildings (51 farms, 42.5\%) and reduction in the use of plant protection products, ploughing straw on arable land and the use of arable land cover with vegetation during winter (figure 1). On the other hand, the least interest (only 20 farmers) is shown in the measures related to set-aside, increasing the share of permanent grassland and reducing the stocking density (per hectare of agricultural land). It proved the willingness to use the production potential of the holding more fully. In the situation of high land prices as well as strong market links of farms in Wielkopolska, this should not come as a surprise.

It is cognitively interesting to recognise some of the characteristics of farms which carry out pro-environmental activities. For this purpose, the actions taken by the farms are listed (grouped into 3 areas) in the context of their relationship with the market, with a division into sales: without previously signed contracts (channel A) and together: with contracts (short- and longterm) and within producer groups and cooperatives (channel B), as well as

\footnotetext{
4 This is indicated by basic data concerning the characteristics of an average holding covered by the survey in comparison with agricultural holdings in Poland covered by the FADN system (data for 2018): area of UAA 29 ha, the density of LU/ha 1.36, the value of agricultural production 237 thousand PLN, agricultural income 82.4 thousand PLN, gross investments 44 thousand PLN, value of equity capital 1286 thousand PLN. In the case of the results of all-Poland FADN farms, it was respectively: 20,5, 0,66, 128, 38, 19, 755 .

5 These are non-standard actions i.e. those that go beyond the measures resulting from the Codex of Good Agricultural Practice, cross-compliance, or those related to receiving payments for greening (crop diversification for farmers with more than 10 ha of arable land, maintenance of ecological areas - for farmers with more than 15 ha of arable land).
} 


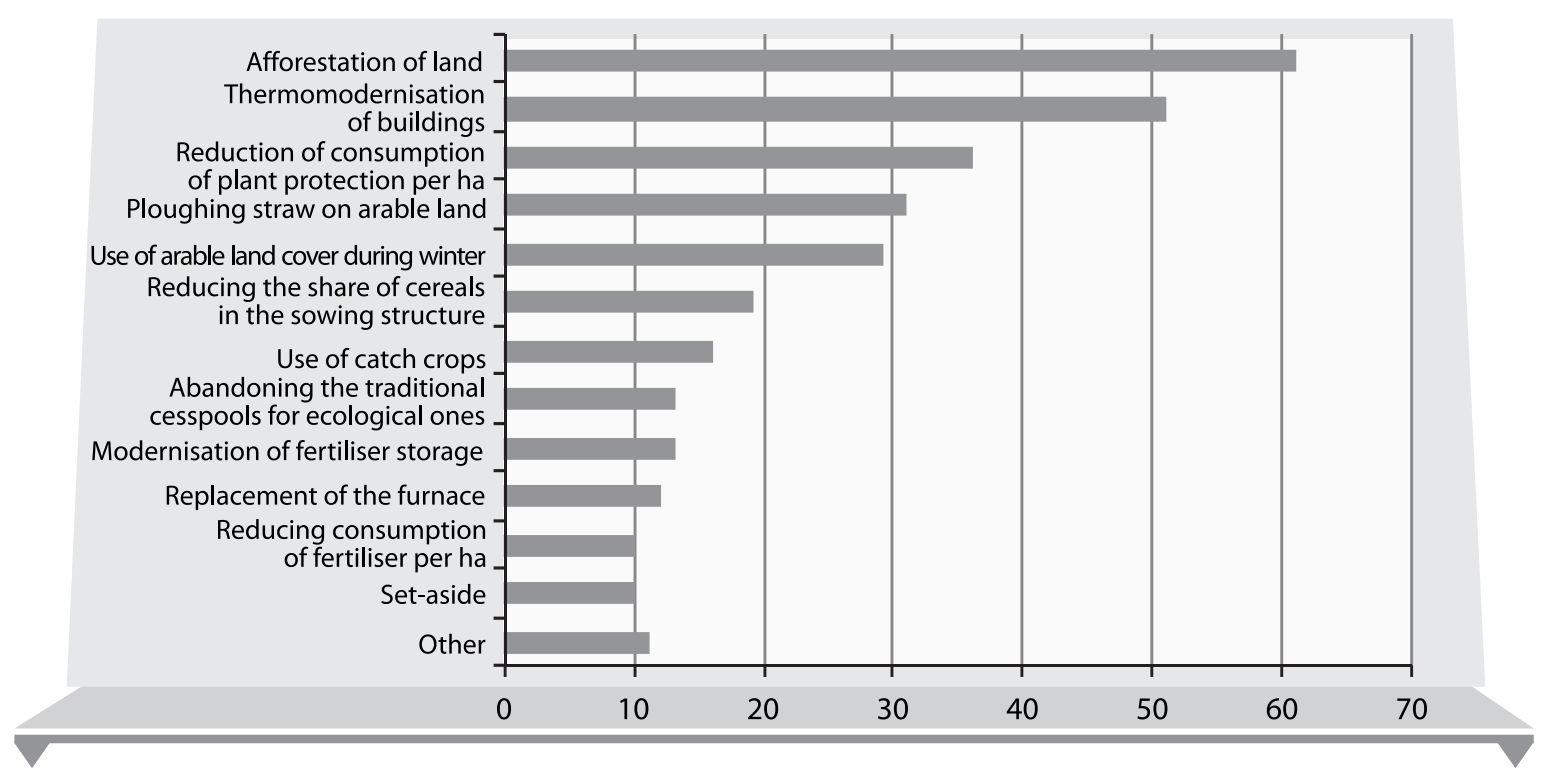

Figure 1. The number of agricultural producers taking actions to improve the natural environment in the examined units in the Wielkopolska region

Each farmer could undertake several environmental measures at the same time, hence the number of responses is higher than the number of holdings surveyed $(N>120)$

Source: own questionnaire survey

both channels $(\mathrm{A}+\mathrm{B})$ (table 1). Each agricultural holding within a specific goods distribution channel could carry out activities from several areas at the same time. Farms integrated with the market to the lowest degree (sellers without contracts) are most involved in land improvement measures (II area of pro-environmental activities) - 71\% of all surveyed farms selling in this way, but only slightly less (67\% of farms) in measures concerning the reduction of agricultural production intensity. A definitely different model of proenvironmental activities is adopted by farms better integrated with the market, i.e. benefiting from short- and long-term contracts or cooperation in a producer group or cooperative. These holdings equally implement land improvement measures and pro-environmental investments. This may suggest that better integration with the market favours undertaking environmental investments in the agricultural holding to a greater extent.

Pro-environmental actions of agricultural

farms - example of holdings

from the Wielkopolska region 
Table 1. Pro-environmental actions undertaken by the surveyed agricultural holdings in Wielkopolska and sales channels of their output (the percentage of agricultural holdings is given in the cells) (in \%)

\begin{tabular}{c|c|c|c}
\hline Specification & I area & II area & III area \\
\hline Sales only without contracts (channel A) & 67 & 71 & 56 \\
\hline Sales based on a contract only (channel B) & 34 & 69 & 69 \\
\hline channels A + B at the same time & 68 & 75 & 45 \\
\hline
\end{tabular}

Actions to reduce the intensity of agricultural production (the area I) include: reducing the use of plant protection products per ha; reducing fertiliser use per ha; reducing stocking density (per 1 ha of UAA- utilised agricultural area); using catch crops; ploughing straw on arable land.

Land improvement actions (the area II) include: afforestation of land; increasing the share of permanent pasture; set-aside; reducing the share of cereals in the sowing structure; using an arable land cover with vegetation during winter.

Investment actions (the area III) include: thermo-modernisation of buildings; replacement of traditional septic tanks for ecological purposes (or sewerage connection); changing the boiler for heating (building, utility room) to a more modern one; modernisation of plant protection products (fertilisers) storage place.

The farmer could declare undertaking pro-environmental actions from different areas at the same time, hence the sum of the values in percentages exceeds $100 \%$. Sales through contracts (channel B) include sales basedon: long-term contracts, short-term contracts; within a producer group or cooperative.

Source: own questionnaire survey

The next table (2) contains a list of pro-environmental actions in the context of the productivity of production factors involved in the surveyed farms. The criterion dividing these farms is the results achieved by an average farm in Poland ${ }^{6}$ in the FADN observation field. Thanks to this, it was possible to observe the involvement of the examined agricultural holdings from Wielkopolska voivodship in pro-environmental initiatives, divided into more and less productive than an average Polish holding. It can be concluded that regardless of the level of productivity, the surveyed agricultural holdings most often engage in activities conducive to land improvement (afforestation of land

6 The results for an average Polish agricultural holding are as follows: land productivity = 4.84 thousand PLN / 1 ha; labour productivity = 34.91 PLN / 1 hour worked in the farm; capital productivity $=161.19$ PLN / 1 thousand PLN of total assets involved in the holding (own calculations based on Wyniki Standardowe...2019). 
(the area II)). It is interesting that for farms less productive than the average in Poland, initiatives related to the reduction of agricultural production intensity (the area I) are on the second place in the hierarchy of undertaken measures. In turn for better, more productive farms (than the average in Poland) investment actions aimed at improving the natural environment are relatively more important. This may prove that undertaking larger investments, also connected with the environment in an agricultural holding, is a derivative of achieving relatively higher productivity of production factors.

\section{Table 2. Pro-environmental actions undertaken by the surveyed agricultural holdings in Wielkopolska and the productivity of individual production factors (the number and percentage are given in the cells)}

\begin{tabular}{l|l|c|c|c}
\hline \multicolumn{2}{c}{ Specification } & I area & II area & III area \\
\hline $\begin{array}{l}\text { Value of agricultural output in thousand } \\
\text { PLN per 1 ha }\end{array}$ & below 4.84 & $28(74 \%)$ & $30(79 \%)$ & $22(58 \%)$ \\
\cline { 2 - 5 } & above 4.84 & $41(50 \%)$ & $56(68 \%)$ & $45(55 \%)$ \\
\hline $\begin{array}{l}\text { Value of agricultural output in PLN / 1 } \\
\text { hour of labour input on the holding }\end{array}$ & below 34.91 & $27(63 \%)$ & $31(72 \%)$ & $21(49 \%)$ \\
\cline { 2 - 5 } & above 34.91 & $42(55 \%)$ & $55(71 \%)$ & $46(60 \%)$ \\
\hline $\begin{array}{l}\text { Value of agricultural output in PLN / 1 } \\
\text { thousand PLN value if assets }\end{array}$ & below 161.19 & $45(63 \%)$ & $52(73 \%)$ & $41(58 \%)$ \\
\cline { 2 - 5 } & above 161.19 & $24(49 \%)$ & $34(69 \%)$ & $26(53 \%)$ \\
\hline
\end{tabular}

The farmer could declare undertaking pro-environmental actions from different areas simultaneously, hence the number of answers in the table is higher than the number of holdings $(\mathrm{N}>120)$. Thresholds for factor productivity are values for a mean result obtained by a farm in Poland, which is covered by the FADN system (Wyniki Standardowe...2019). Areas of activity - as in table 1.

Source: own questionnaire survey

The paper also attempts to synthesize the characteristics of agricultural holdings, which are at the forefront of taking actions aimed at improving the natural environment ${ }^{7}$. The managers of these farms were 51 years old on average,

7 These are the holdings which carried out 5 and more pro-environmental measures (out of 15 listed in the survey) (cf. table 1) in the period 2016-2019. In total, there were 13 such holdings (10.8\% of the surveyed holdings)

Pro-environmental actions of agricultural

farms - example of holdings from the Wielkopolska region 
almost all (92\%) have agricultural education, but at different levels. These farms belong mainly to two production types - $46 \%$ of them are specialised in field crops and $46 \%$ are units without specialisation. On the other hand, the area of agricultural land exceeded 42 ha on average (for comparison, the average size of other farms was $27 \mathrm{ha}$ ). Therefore, they were relatively large units. This is also confirmed by the results of other studies. As Kondratowicz-Pozorska (2016) points out, farms with very high environmental (ecological) standards from the Zachodniopomorskie Voivodeship were characterised by a relatively large UAA. Moreover, they were active in the area of investment and effectively integrated with the market. They were willing to undertake activities such as waste segregation, cleaning household, farmland and roadside areas, afforestation of wasteland, as well as cleaning and deepening drainage ditches. The relatively large area of the UAA of agricultural holdings actively undertaking proenvironmental measures results from the fact that in larger holdings (although not the largest ones) there are wider possibilities of undertaking pro-environmental actions. It results the financial resources available, and perhaps there is stronger social pressure. The own attitudes of agricultural producers (also as consumers) towards the environment are not without significance. On the other hand, however, as Gotkiewicz and Klimecki (2016) indicate, based on surveys of farms in Ostróda County (Warmińsko-Mazurskie Voivodeship), financial incentives encourage farmers to undertake pro-environmental activities (participation in agri-environmental programmes under the Common Agricultural Policy), and the awareness and approach to environmental protection are less important.

When analysing environmental issues, it is worth noting that the farms which showed the highest activity in terms of pro-environmental actions had average fertiliser consumption at the level: 0.51 tons per 1 hectare. For comparison, in the group of all other surveyed farms, fertilizer consumption was on average $0.48 \mathrm{t} / 1$ ha UAA. Interestingly that $46 \%$ of the managers of these farms plan to implement photovoltaic panels in the farm (for comparison, in the group of other farms it was 33\%). Moreover, the average boiler for heating the house was 5 years old, while for the remaining group 7.2 years, and at the same time, $69 \%$ of the residential buildings of these units had thermo-modernisation, while in the remaining units it was $50.5 \%$. This may indicate a relatively lower environmental pressure in this aspect.

From the economic point of view, the following features of these farms can be mentioned: agricultural income in 2018 was at the level of 112000 PLN (as compared to PLN 79000 for other units), the value of assets was about 2.1 million PLN, of which $67 \%$ was the value of land (in other farms it was respectively 
1.3 million and 70\%). Moreover, productivity of labour and assets respectively: 68 PLN/1 hour of labour input and 164 PLN/1 thousand value of assets. These farms are thus stronger linked to the market, have greater resources in these assets and achieve relatively high productivity (especially labour productivity) against the background of agricultural holdings in Poland (cf. table 2). On the other hand, in the case of investment activity (the average level of investment was 77 thousand PLN, as compared to 41 thousand PLN in the case of the remaining surveyed farms). Among the most important directions of future development, managers of these farms indicate facilitation of work, an increase in income, and in production. On the other hand, among the planned changes, the least important are the changes in the direction of production in a holding, which may result from significant investments and risks connected with this. Similar conclusions, but from an eco-efficiency ${ }^{8}$ perspective, can be found in the study of Czyżewski`s team (2020). They point out that higher eco-efficiency is achieved in regions of the EU with higher production intensity, and the drivers of eco-efficiency are investments and environmental subsidies.

In the context of the presented results, it appears that it is easier for larger farms to implement pro-environmental measures. This is due to easier possibilities for financing such actions and, in general, better management of production resources (education, training). Simultaneously, nowadays investments are increasingly environmentally friendly, also by reducing the energy intensity of production. These issues are not explicitly evaluated in the literature. On the one hand, it is indicated that small farms are more environmentally friendly (Ripoll-Bosch et al., 2012). On the other hand, it is stressed that larger farms achieve a higher level of sustainability (Gomez-Limon and Sanchez-Fernandez, 2010). These farms find it easier to implement eco-innovations or production techniques that are more environmentally friendly. Thus, one of the conditions for undertaking pro-environmental actions, including environmental investments at the level of farms, is (usually) capital. Many times, smaller farms with limited income do not undertake investments related to environmental welfare in a broad sense. Frequentlysmaller farms with limited income do not undertake investments related to the broadly understood environmental welfare due to lack of funds (Grzelak et al., 2020) or a lower concentration of professional activity on agricultural activity. Also, Clement et al. (2011) noted that not enough capital

8 Eco-efficiency = value of agricultural output / environmental input (e.g. energy, fertiliser, value of consumption of plant protection products)

Pro-environmental actions of agricultural

farms - example of holdings

from the Wielkopolska region 
resources (i.e., potentially lower sustainability in economic terms) limit the potential and interest of a farm to implement eco-friendly agricultural practices. Relatively complicated procedures for using programs (e.g. agro-environmental) or relatively high transaction costs for small units may also be a barrier. Overcoming these difficulties is in practice implemented through a separate payment system for small farms within the CAP or a support program (e.g. subsidies for the restructuring of small farms) (Kokoszka, 2014). Although these instruments are not directly related to the environment, they indirectly increase the chances of agricultural producers' activities for pro-environmental measure by increasing income. Also, the currently existing support programs for the development of alternative energy sources ("My electricity" or "Agroenergy") have an impact on reducing the environmental impact of agricultural producers and are part of a low-carbon economy.

\section{Conclusions}

The considerations presented in the article lead to conclusions:

1. The issue of pro-environmental activity on farms is complex due to the integration of the economic and environmental dimensions, which requires further scientific knowledge. This concerns, in particular, issues relating to the impact of the scale and intensity of farm production on the environment, as well as the assessment of the effectiveness of stimulating pro-environmental activity at the level of the EU Member States. A further pro-environmental direction should be continued within the framework of the CAP of the EU, but with greater consideration for the size of farms and their spatial dimension. Therefore, Member States should have greater flexibility in terms of shaping detailed requirements relating to stimulating environmental activities.

2. The examined farms in Wielkopolska, which undertook pro-environmental activities in the period 2016-2019, most often implemented it in the area of land improvement. It was noted that the formalisation of market contacts of agricultural holdings (sales based on contracts) favoured pro-environmental investments. In the case of agricultural holdings with higher production factors than average in the country, the share of pro-environmental actions relating to the reduction of production intensity was relatively lower compared to other dimensions of environmental measures.

3. The agricultural holdings which showed the highest activity in the scope of undertaken pro-environmental measures (ca. 11\% of the surveyed) were stronger connected with the market, managed on a larger area of the UUA, 
achieved higher incomes, had a greater value of assets, invested more in comparison with other holdings, achieved higher productivity in comparison with agricultural holdings in Poland. The managers of these farms, despite their rather high age, are open to innovative ecological solutions (e.g. half of them are planning to install photovoltaics). It is easier for larger farms to carry out pro-environmental activities due to the wider possibilities of income creation and greater creditworthiness. In this way, they can mitigate pressures on the environment by relative reducing greenhouse gas emissions from low emissions, impacts on groundwater or soils (using land improvement measures).

4. Economic and environmental sustainability is easier to achieve for larger farms ${ }^{9}$ because of the possibilities to finance specific activities and related investments. Incentives for related activities should be stronger, e.g. perhaps even higher standards under the so-called good agricultural practices, or stronger pro-environmental support for smaller units in the form of e.g. green investment grants.

5. There are reserves in the scope of reducing the impact of agricultural holdings on the environment through the implementation of relevant activities and investments. This concerns in particular issues related to thermal modernization of buildings, use of alternative energy sources, or possibly a new generation of boiler for heating, replacement of traditional septic tanks with ecological ones (if there is no possibility of sewage connection), as well as the application of land improvement measures. In the case of smaller farms, there is a greater need to implement measures in the area of pro-environmental investments. In turn, in larger units, actions reducing production intensity, and in all groups concerning land improvement.

6. In the light of the presented conclusions, it seems justifiable in the next EU budget perspective to support even more pro-environmental measures of agricultural farming. The idea is both to directly stimulate activities that raise environmental standards (also using cross-compliance principles) and to indirectly improve knowledge through training. It is also important to leave more freedom to the Member States to define beneficiaries and detailed frameworks for action, taking into account regional differences.

9 In our study, the largest farms were from the ES5 class. It can be assumed, based on the results of other authors' research (Zegar, 2009), that environmental sustainability can be a linear function of the size of a farm to certain limits beyond which sustainability is reduced. However, this goes beyond the scope of this study.

Pro-environmental actions of agricultural

farms - example of holdings

from the Wielkopolska region 


\section{Summary}

Pro-environmental actions of agricultural farms - example of holdings from the Wielkopolska region

The main aim of the article is to identify pro-environmental actions in farms in the Wielkopolska region. The article uses the results of surveys carried out in 2020 in a group of 120 agricultural holdings from Wielkopolska running agricultural accounting according to the FADN (Farm Accountancy Data Network) system. The time scope of the analyses referred to the period 20162019, and in the case of economic data to 2018. The issue of proenvironmental activity on farms is complex due to the integration of the economic and environmental dimensions, which requires further scientific knowledge. It was found that the investigated farms in Wielkopolska, which undertook pro-environmental actions, most often realized it in the area of land improvement. The farms which showed the highest activity in terms of undertaken pro-environmental measures were more strongly connected with the market. The managers of these farms are open to innovative ecological solutions despite their quite high age (e.g. half of them are planning to install photovoltaics). It was also found that it was easier for larger farms to carry out pro-environmental measures due to the wider possibilities of income creation. In the case of smaller farms, there is a greater need to implement measures from the area of pro-environmental investments. In turn, in larger units, measures reducing production intensity, and in all groups concerning land improvement.

Key words: farm, environment, income, Wielkopolska.

\section{Streszczenie}

Działania prośrodowiskowe gospodarstw rolnych - przykład gospodarstw z Wielkopolski

Głównym celem pracy jest rozpoznanie działań prośrodowiskowych w gospodarstwach rolnych w Wielkopolsce. W artykule wykorzystano wyniki badań ankietowych zrealizowanych w 2020 roku w grupie 120 gospodarstw rolnych z Wielkopolski prowadzących rachunkowość rolną według systemu FADN. Zakres czasowy analiz odnosił się do okresu 
2016-2019, a w przypadku danych ekonomicznych do roku 2018. Problematykaaktywności prośrodowiskowejgospodarstw rolnych jest złożona ze względu na integrację wymiaru ekonomicznego i środowiskowego, co wymaga dalszego poznania naukowego. Stwierdzono, że badane gospodarstwa rolne w Wielkopolsce, które podejmowały działania prośrodowiskowe najczęściej realizowały to $w$ obszarze dotyczącym poprawy stanu gruntów. Gospodarstwa, które wykazywały się najwyższą aktywnością $\mathrm{w}$ zakresie podejmowanych działan prośrodowiskowych były silniej powiązane $\mathrm{z}$ rynkiem. Kierownicy tych gospodarstw pomimo dość wysokiego wieku są otwarci na innowacyjne rozwiązania ekologiczne (np. połowa z nich planuje zainstalowanie fotowoltaiki). Stwierdzono również, że większym gospodarstwom łatwiej jest prowadzić działania prośrodowiskowe ze względu na szersze możliwości kreacji dochodów. W przypadku gospodarstw mniejszych istnieje większa potrzeba realizacji działań z obszaru inwestycji prośrodowiskowych, w większych jednostkach z kolei działania obniżające intensywność produkcji, a we wszystkich grupach dotyczące poprawy stanu gruntów.

\title{
Słowa
}

kluczowe: gospodarstwo rolne, środowisko, dochody, Wielkopolska.

\author{
JEL \\ Classification: Q15, Q18, Q56, Q57
}

\section{References}

Ahmed, S., Stepp, J.R. (2016). Beyond yields: Climate change effects on specialty crop quality and agroecological management. Elementa Science of the Anthropocene, 4. DOI: http://doi.org/10.12952/journal. elementa.000092.

Baum, R., Bieńkowski, J. (2020). Eco-efficiency in measuring the sustainable production of agricultural crops. Sustainability, 12(4). DOI: $10.3390 /$ su12041418.

Clement, F., Haileslassie, A., Ishaq, S., Blömmel, M., Murty, M.V., Samad, M., Dey, S., Das, H., Khan, M.A. (2011). Enhancing Water Productivity for Poverty Alleviation: Role of capitals and institutions in the Ganga Basin. Experimental Agriculture, 47, 133-151.

Czyżewski, B., Matuszczak, A., Grzelak, A., Guth, M., Majchrzak, A. (2020). Environmental sustainable value in agriculture revisited: How does

Pro-environmental actions of agricultural

farms - example of holdings

from the Wielkopolska region 
Common Agricultural Policy contribute to eco-efficiency?, Sustainability Science, 15(5), 1-16. https://doi.org/10.1007/s11625-020-00834-6.

DG AGRI (2017). Modernising and simplifying the CAP. Background Document Climate and Environmental challenges facing EU agriculture and rural areas, Brussels, https://ec.europa.eu/info/sites/info/files/ food-farming-fisheries/key_policies/documents/env_background_ final_en.pdf.

D'Souza, G., Ikerd, J. (1996). Small Farms and Sustainable Development: Is Small More Sustainable? Journal of Agricultural Economics, 28, 73-83. FAO (2014). Building a common vision for sustainable food and agriculture. Principles and Approaches, Rome, http:/ / www.fao.org/3/a-i3940e.pdf. Gomez-Limon, J.A., Sanchez-Fernandez, G. (2010). Empirical evaluation of agricultural sustainability using composite indicators. Ecological Economics, 69 (5), 1062-1075.

Gotkiewicz, W., Klimecki, T. (2016). Działania prośrodowiskowe $\mathrm{w}$ gospodarstwach rolnych ze szczególnym uwzględnieniem programu rolnośrodowiskowego (Pro-environment activities in agricultural holdings with the emphasis on agri-environmental programs). Roczniki Naukowe SERiA, XVIII (5), 36-40.

Grzelak, A., Staniszewski, J., Borychowski, M. (2020). Income or Assets What Determines the Approach to the Environment among Farmers in A Region in Poland? Sustainability, 12. DOI:10.3390/su12124917.

Kelly, E., Latrufe, L., Desjeux Y., Ryan M., Uthes S., Diazanabakana A., Dillon E., Finn J. (2018). Sustainability indicators for improved assessment of the effects of agricultural policy across the EU: Is FADN the answer? Ecological Indicators, 89, 903-911.

Kondratowicz-Pozorska, J. (2016). Ekologiczne gospodarstwa rolne jako stymulatory rozwoju lokalnego i wspólnot lokalnych (Organic Farms as Drivers of Local Development and Local Communities). Studia i Prace WNEIZ US, 46 (1), 335-343. DOI:10.18276/sip.2016.46/1-26.

Martinho, V., João, P.D. (2019). Best management practices from agricultural economics: Mitigating air, soil and water pollution. Science of The Total Environment, 688, 346-360. DOI: 10.1016/j.scitotenv.2019.06.199.

Piwowar, A. (2020). Attitudes and opinions of farmers in the context of environmental protection in rural areas in Poland. Environmental Monitoring and Assessment, 192 (3). DOI: 10.1007/s10661-020-8133-5.

Ripoll-Bosch, R., Díez-Unquera, B., Ruiz, S. R., Villaalba, M.D., Molina, E., Joy, T.M., Olaizola, T.A., Bernués J.A. (2012). An integrated sustainability assessment of mediterranean sheep farms with different degrees of intensification. Agricultural Systems 105, 46-56. DOI:10.1016/j. agsy.2011.10.003.

Rogall, H. (2004). Ökonomie der Nachhaltigkeit. Handlungsfelder für Politik und Wirtschaft. VS- Verlag, Wiesbaden. 
Stoate, C., Báldi, A., Beja, P., Boatman N., Herzon, I., Van Doorn, A., de Snoo, G., Rakosy, L., Ramwell, C. (2009). Ecological Impacts of Early 21st Century Agricultural Change in Europe-A Review. Journal of Environmental Management 91 (1), 22-46. DOI: 10.1016/j.jenvman.2009.07.005.

Sulewski, P., Kłoczko-Gajewska, A. (2018). Development of the sustainability index of farms based on surveys and FADN sample. Problems of Agricultural Economics 356 (3), 32-56. DOI: 10.30858/zer/94474. Syp, A., Osuch, D. (2019). Dairy farmers' views on environment, results of questionnaire survey from regions of Mazowsze and Podlasie in Poland. Engineering for Rural Development, 18, 751-757. DOI: 10.22616/ erdev2019.18.n067.

Śmiglak-Krajewska, M. (2018). Cultivation of Legume Crops in the Context of Sustainable Agriculture. Roczniki Naukowe SERiA XX (6), 255-261. DOI: 10.5604/01.3001.0012.7770.

Świtek, S., Sawińska, Z. (2017). Farmer rationality and the adoption of greening practices in Poland. Scientia Agricola, 74(4), 275-284. DOI: 10.1590/1678-992X-2016-0167.

Westbury, D.B., Park, J.R., Mauchline, A.L., Crane, R.T., Mortimer, S.R. (2011). Assessing the environmental performance of English arable and livestock holdings using data from the Farm Accountancy Data Network (FADN). Journal of Environmental Management, 92, 902-909.

Wyniki Standardowe 2018 otrzymane przez gospodarstwa rolne uczestniczace w polskim FADN (2019). Opracował zespół: Floriańczyk Z., Osuch D., Płonka R. Warszawa: IERiGŻ-PIB.

Zasępa R. (1972). Metoda reprezentacyjna. Warszawa: PWE.

Zegar, J. (red.) (2009). Z badań nad rolnictwem społecznie zrównoważonym. Toczyński, T., Wrzaszcz W., Zegar, J. Warszawa: IERiGŻ-PIB.

Żylicz, T. (2004). Ekonomia środowiska i zasobów naturalnych. Warszawa: PWE. 